\title{
Forming Gorilla Convict Inside the Belly of the Beast Seth Ferranti
}

$\mathrm{I}^{\mathrm{h}}$

had a 25 -year sentence when I was 22 years old. That was crazy, being sentenced to more time than how old I was. It was a struggle for real, but I had to do something to secure my future. I was doing time, but like they say in the pen, "Do the time. Don't let the time do you".

I fancied myself a writer. And in the depths of the netherworld of corruption and violence, it is not like you can just fancy yourself anything. I had affectations to be Hunter S. Thompson or Henry Rollins or Jim Morrison. A rock-n-roll poet of epic proportions. But I couldn't be who I was. Not in prison. You have to keep your guard up and put on the tough guy façade or else the predators will be on you quick.

Not that I was a tough guy or anything. I was middle-class and from the suburbs. As far from a criminal as I could be, I thought. I sold LSD and marijuana on the college circuit. No guns, no violence, no criminal organization. But the feds thought differently and called me a kingpin.

So here I was in prison left with nothing but my thoughts and my dream of being a writer. My dream of expressing myself from deep inside the prison-industrial complex. A dream that seemed so farfetched I didn't even know if I would be able to accomplish it. But I saw that others had done it before me, so I figured why not? If I put the hard work and effort in I can potentially make anything happen. Even from prison.

Jack Henry Abbott, Mumia Abu Jamal, and George Jackson became my inspirations. If they could write books from the pen, why couldn't I? I read as many books as I could from prison authors. I had a voracious appetite for literature and after I finished with the prison classics I moved on to the books on the Mafia guys. I was in federal prison on the East Coast so there were tons of mob dudes. I wanted to read their stories and find out who they were.

It was around this time that I started formulating my plan to be a writer. The first thing I did was start reading about self-publishing. I probably read thirty books on self-publishing. I didn't want to go the route of vanity publishing. I wanted to form my own independent house. This was when urban fiction was blowing up and Teri Woods' True to the Game, K'wan's Gangster and Vickie Stringer's Let That Be the Reason were making their rounds in prison.

I didn't want to write fiction. I wanted to write about real life. The life I was living and the experiences of the men around me. I heard all kinds of 
stories that you can only hear in prison and I was very intrigued. I knew I could tell these stories. I was on the compound with some very notorious dudes. I didn't want to write about the mob dudes though. I wanted to do something more cutting-edge.

In the mid-90s gangsta rap was very, very popular in the world, and in prison even more so. I used to watch the rap videos in the black TV room, and the rappers would namedrop the street legends from their respective hoods and states in their songs. I started catching conversations about the gangsters that hip-hoppers were mythologizing.

I found out that some of the more infamous street legends were on the same compound as me. That's when I got the idea to write books about them. I was very interested in reading about them and there were no books to be found. I used to go to the law library to read about their cases. I came up with a plan and outline, and approached some of the dudes I wanted to write about.

I couldn't offer them money for their stories, but I could offer them the chance to tell their side. I would research the court records, read the newspaper articles, and interview the subjects, and then write a concise, detailed story of their lives and journeys to the top echelon of the criminal hierarchy. I didn't glorify. I wrote a cautionary tale. Like this is what happens if you go this route.

I started putting books out in 2005, forming my publishing house and my website. I was also writing for various magazines and websites like VICE, HoopsHype, Don Diva and F.E.D.S. My niche was prison life, prison basketball and street legends. I was very lucky to have my wife to facilitate everything on the outside. Without her, Gorilla Convict would have just been an idea in my head and I would have been another frustrated writer that couldn't get anything done.

With my careful planning and her putting my ideas into motion, we built a publishing house and brand. It was a struggle and I always tell people that running a career from prison was like being handcuffed and trying to write, but I did it. I preserved and I didn't give up. I was relentless. I set the goal and I executed. That was the biggest thing for me.

I always tell people that my biggest talent is my ambition, my ability to work and get things done. I have tons of ideas, but I work on what I have a passion for, which allows me to finish the project and get it out to the world. We started having some success with the company and books. And when 
I got out in 2015, I had something to walk into, work wise that is. When I started it was just something that I wanted to do. I wrote the stories and published the books because I wanted to. I didn't care if anybody bought them, but it was nice that they did.

\title{
CONTACT INFORMATION
}

\author{
Seth Ferranti
}

http://www.sethferranti.com 